\title{
Stage IC Ovarian Germ Cell Tumor AJCC v6 and $v 7$
}

National Cancer Institute

\section{Source}

National Cancer Institute. Stage IC Ovarian Germ Cell Tumor A/CC v6 and v7. NCI

Thesaurus. Code C6293.

Stage IC includes: (T1C, N0, M0). T1c: T umor limited to one or both ovaries with any of the following: capsule ruptured, tumor on ovarian surface, malignant cells in ascites or peritoneal washings. N0: No regional lymph node metastasis. M0: No distant metastasis. (AJCC 6th and 7th Eds.) 